\title{
Individual Savings Problems \\ An Analysis of Commercial Banks in Tanzania: Evidence from CRDB Bank Marangu Branch
}

\author{
Ansgar J. Sakaya ${ }^{1} \quad$ Lyimo, Joshua Amani ${ }^{2}$ \\ 1.Department of business studies, Mzumbe University, Mbeya Campus College P.O box 6559, Mbeya, Tanzania \\ 2.Student Bachelor Degree of Accounting and Finance in Business Sector (BAF-BS) Department of business \\ studies, Mzumbe University, Mbeya Campus College P.O box 6559, Mbeya, Tanzania
}

\begin{abstract}
This study examines the reasons as to why people do not save. A survey design was employed on 130 respondents of CRDB Bank Marangu Branch. Purposive and random sampling techniques, questionnaire and Interview method were used for data collection. Again, data were analysed descriptively.

Results of the study found that, CRDB bank has not yet been effective in the creation of financial capability and training programmes that would teach people best practices, such as basic budgeting, and separating money saved for different goals and uses. Individuals were found to have negative attitude toward saving with Bank due to opening and operating cost of the account. The efforts and resources placed by CRDB Bank in promoting savings are high compared to the saving rate as most of the opened accounts become dormant in one year after been opened and most of products available with the branch are not known well by majority, in hand with that, most of People residing in Marangu are low income earners and therefore they save much of their earnings informally and at shorter intermittent level. Lastly, interest rates and individual income were seen to impact levels of saving habit. Moreover, the study suggested that, bank staff need to be assisted in realizing their role in mobilizing individual saving, the bank should also create awareness to public on saving plan, a regular snap check of account opened, existing one to ensure their activeness and provide reason for any inactive account, as well as design new products or facility to promote savings, review cost, procedures and interest rates. Again the bank should motivate individual habit of participating in financial education workshops as well as promoting individual saving habit programmes by the bank to Primary, Secondary, College and University students to help them grow with the mentality of saving. The policy makers should try to sensitize the rural people of Marangu to diversify some of their land uses into non agricultural activities such as to conduct various business activities that would guarantee income generation so as to increase saving rate. The bank should design adverts demonstrating the value of having savings for the purpose of changing rural people's attitude towards saving.
\end{abstract}

Keywords: Saving attitude, Commercial Banks

DOI: $10.7176 / \mathrm{EJBM} / 11-11-07$

Publication date: April $30^{\text {th }} 2019$

\section{Introduction and motivation of the study}

Prediction of future circumstances in life is uncertain and individual decision towards saving becomes as hard as they do not have a room to have enough information, time and silks to do so (Gustman \& Steinmeier, 2004). Normally, a bank performs all of its function by collecting funds from the public as a source of its capital and put back economy at borrowers cost. Savings are essential element of economy as they contribute to the part of national income as an accumulation for future projects. Individual saving are important as they help in meeting transaction motives, precautionary motive and speculative motives (Msabila, 2001). Individual savings behavior has a significant occupation in the areas of microfinance research, and a recently noted issue relating to saving has been a general decline in household saving rates since the 1980s, which is now calling for an explanation (Erkki \& Jouko, 1992), in hand with that, the low rate of individual saving has made consumers unprepared for their customary role of pulling the economy out of recession, this is according to Lacy Hunt, chief economist for the Hong Kong Bank Group in the United States (Roy \& Webb, 1992)

Individual saving has posed a considerable interest in the economics literature with particular focus on the various motivations behind saving behavior, which are possibly complex, and interrelated (Sarah \& Karl, 2016). High individual saving does benefit the households and the nation at large as the fund saved is used to finance various investments by banks that impact the whole society's well being; high individual savings will only be possible if the level of financial literacy is well imparted to individual. (Mahdzan \& Tabian 2013). Individual savings are determined by income level, prospective development, taxation policy, and the age structure of the population and expectations hold by financial institutions (Thirlwall, 2002). However, Browning and Lusardi (1996), discussed motivations for savings in their study by focusing on those listed by Keynes and such motivations includes: precautionary saving where households hold a contingency fund in case of adverse future events; to smooth income, consumption over the life cycle and the inter-temporal substitution motive, whereby households 
benefit from accumulating interest on savings (Keynes, 1936). Clearly, motives for saving will differ across households as well as over time for a given household. Such motives are likely to be interrelated and, indeed, complementary. For example, a household which saves to accumulate interest from savings will also hold a fund to be used should unforeseen adverse events occur. Regardless the motivations behind saving behaviour, a commonly held view is that, individuals and households are not saving enough in the context of both short-term saving as well as long-term saving for retirement (Crossley, Emmerson, \& Leicester, 2012).

It should be remembered that, many people do not save due to unpredictable income like those who are not being employed, others are low income earners, that they cannot have a portion to save as the whole money is exhausted for the family purposes; people have different priorities, changes in age and family circumstances like retirement, family expansion or stop working, Critical healthy, excessive borrowings (having multiple loans at once) as well as negative attitude towards saving as people have perception that, putting money in banks is benefiting a particular bank alone. Also, bank employees have negative attitude towards low income earners that, their savings' with bank do not have significant contribution to bank capital accumulation, moreover people have no confidence with the saving institution, people are skeptical with government regulations towards banking sector like what happened to some banks that were closed down in 2017 and 2018; poor marketing practices like promotion activities that are taking place mostly in town areas and leave behind remote areas which some of them have people with money and would like to save, but they lack information about saving programmes, poor savings return. Individual savings in developing countries like Tanzania should be highly promoted and financial institutions should struggle to find better mechanisms to help people to save more. This will help the banks to increase their capital flow for investments of which people can benefit from the investments made and the saving amount can help them when their incomes are not predictable (Campson et al., 2000).

To have stable economy, the government as well as private sector need to come up with various policies towards achieving better and stable economy and more importantly to reduce the level of poverty, in both at individual level and nation level at large. The Government of Tanzania through her governing Bank, the Bank of Tanzania (BOT) and financial sector, Banks in particular, established many policies and principles governing savings realizing saving motives. Researchers have come up with different attitude on the issue of individual saving, and that being the relationship between saving and individual economic growth. Moreover, contradiction exists to whether interest rates charged and offered by financial institution affect savings. Hence, the need for promoting individual saving is of high important for up keeping healthier output of the economy and other development investment. So, for higher capital accumulation and funding of additional investments, individual savings needs to be stimulated to the reasonable level (Thirlwall, 2002).

At economic point of view, in order to save, one will have to forgone the current consumption; the question remains how financial institution insures these people postpone the current consumption and save? The other one is individual and household behavior, and attitude towards savings. To date, financial institutions in Tanzania Mainland are expanding at increasing rate while interest rates for deposits are decreasing. The question that remains is, what is the impact of decreasing interest rate on saving behavior? Hence, this study is significant as it will save as a useful tool in understanding the general behavior of savings and give insightful information as to why individual in the area have poor savings with the Bank.

\subsection{Objectives of the study}

i. To find out the reasons of CRDB Bank to have many dormant savings accounts.

ii. To examine individual attitude towards savings habit at CRDB Bank.

\subsection{Usefulness of the study}

The study is useful to the management of CRDB Bank as it will assist them to come up with new strategies towards improving individual saving behaviour.

\section{Literature Review}

\subsection{Overview of Deposit Target}

The term "deposit target" is used to denote the deposit mobilization strategy of banks where operation teams are given certain period of time to mobilize deposits from anywhere up to a certain amount (Mohammed, Alexande, \& Musa, 2015). In the banking institutions there are rewards and punishment for meeting or not meeting the target, while the implementation of this policy differs from bank to bank. This practice is common among the new generation banks. For meeting the deposit target certain percentage of money are added to the banker's income, which enhances his/her chances of good performance appraisal and subsequent promotion and job security. For new employees it gives them quick confirmation of appointment during the probationary period. However, failure to meet the deposit target is always unpleasant, resulting to no promotion, loss of job etc, hence, individual saving behavior rest on deposit target; the higher target of banks deposit the higher the effort in promoting individual saving habit. This is why Banks have to mobilize deposits from both urban and rural areas from the rich and the less endowed as an input to facilitate their daily operation and investment (Oboh, 2005). Deposits, according to 
Aliyu (2010), are funds that customers place with a bank and that the bank is obligated to repay on demand, after a specific period of time or after expiration of some required notice period. It can also be defined as the money and other securities trusted to banks and are subjected to demand (Edla, 2018). Therefore, Financial Institutions in Tanzania have also been granted with licenses to accept deposit from their customers. Deposit has become the main target of financial institution since without deposit there is no quick and adequately source of fund to run financial institution. Deposit mobilization is the most important function of commercial banks since their successful operations depend on the extent of funds mobilized from individual savings. In Nigeria for example, the government has directed banks from time to time to make all possible efforts to mobilize new deposits, which can expedite the pace of lending activities (Mohammed, Alexande and Musa, 2015). According to Walter (2007), Bank as a financial institution plays a vital role in promoting bank habit among individuals. Again, Banks are able to perform this faction by hardening saving to form capital, which in turn ploughed into the economy in form of investment, tht contributes to financial growth of the nation.

\subsection{Financial Reform}

Liberalization of financial market has swept over much of the developing world especially since the mid-1980s. This liberalization has been characterized by greater scope being granted to market forces in determining interest rates and in allocating credit (Caprio, Atiyas and Hanson 1994). Although this has occurred under the pressure of increased globalization of financial markets, and following the example of many industrial countries, there has been an expectation that financial liberalization would help economic development. In particular, the early literature on financial repression, following McKinnon (1973) and Shaw (1973), who stressed the potential role of higher interest rates in mobilizing savings that could be put to productive use.

\subsection{Financial Literacy and Financial Advice}

Low financial literacy and a lack of information affect one's ability to save. Ignorance about basic financial concepts can be linked to a lack of retirement planning and a lack of wealth accumulation. In the United States for example, several initiatives have been undertaken to foster saving and financial security, such as educating workers in order to improve their financial literacy and knowledge about pensions, automatically enrolling workers in pension plans, and simplifying their pension enrollment decisions. Some individuals are uninformed about the most important components of their total retirement savings plan and lack basic financial knowledge advice (Annamaria, 2000). In fact for the case of Tanzania, only a small fraction of households consult financial advisers, bankers, certified public accountants and other professionals. Majority of households rely on informal sources of advice, which sometimes is not reliable as in the case of France, whereby a good number of individuals relay on family or friends in making financial decision. This has always been found to people with low income (Lusardi, 2003). Individuals with low financial literacy are more likely to relay on families and friends to make financial decision, while those who have financial knowledge depends on newspapers, internet, magazine and books as their source of financial information(Van, Lusardi, \& Alessie 2007).

\subsection{Inflation}

It is often argued that, when price increases are expected, expenditures are advanced in time. If the expenditures are on investment goods, measured saving will increase; otherwise, consumption increases. So, Paul (1977) tries to tell us that, there is effect of inflation on individual saving. Inflation is viewed as an undesirable phenomenon, and its presence is associated with increased pessimism about economic conditions, which may lead to increase saving for precautionary reasons, although this hypothesis is unsatisfactory because it relies upon a tenuous psychological link between inflation and uncertainty to explain the increase in saving in inflationary times. Hence, it can be argued that, the increased saving is a precautionary response to the increase in uncertainty. Saving is determined by both the expected level of real income and the certainty with which those expectations are held. The greater the uncertainty of expectations like the effect of unemployment or general economic conditions on money income expectations, the greater will be saved (Paul, 1977). Inflation also affects saving behavior indirectly through its effect on either determinants of saving. In particular, inflation will affect interest and the real wealth of households. The real wealth of households' financial wealth is often eroded in inflationary periods, and an attempt by individuals to maintain the purchasing power of their stock of financial assets will lead to higher saving. Inflation reduce real financial wealth and thus induces saving only when rate of return fail to incorporate' an inflation premium. In the long run, rates of return either adjust to include an inflation premium or consumer reallocates their portfolio. Any long-run inflation effect on saving is likely to reflect uncertainty rather than a wealth effect. Furthermore, the wealth effect should apply primarily to financial assets and not to other forms of saving, since the real value of the flow of services from the stock of durables is unchanged (Paul, 1977).

\subsection{Attitude, Trust and Perception of Individual towards Saving}

Financial Institutions are basically pivot of trust, sustained by attitude and managed by complex financial 
management skills and psychology of human relations. The more the customer trust services provided by the institution the higher the perceived value of the relationship (Walter, Holzle, \& Ritter, 2002).

\subsection{The Effect of Interest-Rate Changes Lifecycle Consumer}

People are always looking forward when choosing their current consumption and saving; they consider not only their current income and desires, but also their future income and desire as well as to maximize lifetime well-being (utility) subject to the constraint imposed by lifetime income which is budget constraint. Poorer interest rates are seen to be unfair among older people (Wells, 2008) and also it affects individuals' intentions to open saving accounts (Hall et al, 2007; Kempson et al, 2006).

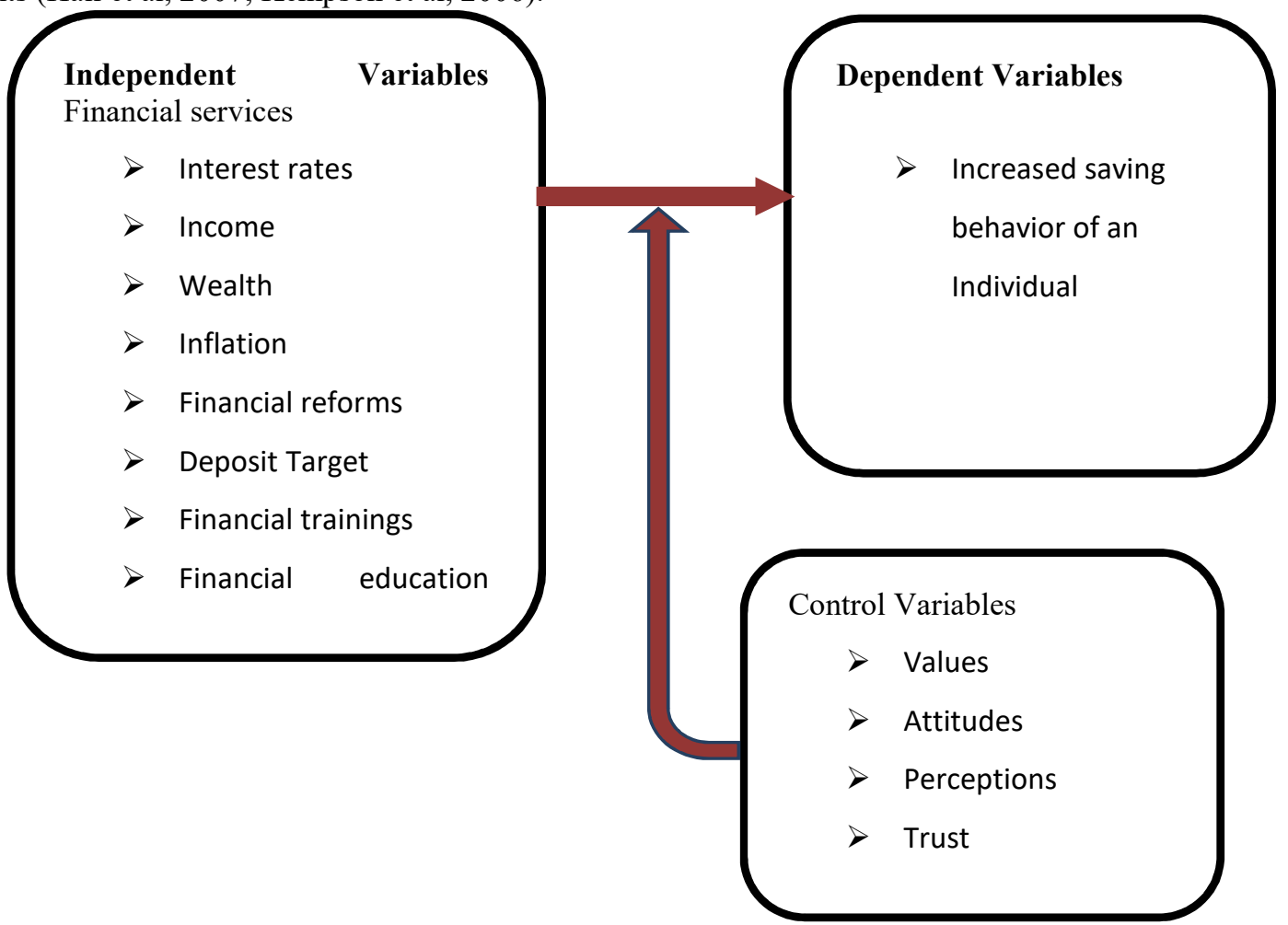

Figure 2. Conceptual Framework of the Study

\subsection{The Study Area}

The study was administered in Kilimanjaro Region at Moshi Rural District and was centred at CRDB Bank Marangu Branch. Marangu Branch serves two wards; Eastern Marangu with a total population of 23,734 and Western Marangu rural with a total population of 18,976 according to Population Census of 26/08/2012. The motives for choosing the rural branch was to know the attitude of individuals in rural areas towards saving as services offered by this institution as mainly directed to rural community where majority of people are below the poverty line and also to find out the Problems encountered by CRDB Bank in rural areas towards promoting individual saving.

\subsection{Research design}

Research design is the arrangement of conditions for collection and analysis of data in a manner that aims to combine relevance to the research purpose with economy in procedure. In fact, the research design is the conceptual structure within which research is conducted; it constitutes the blueprint for the collection, measurement and analysis of data (Kothari, 2004). This study was a survey design and it was used for the purpose of accessing direct data from clients of CRDB Bank Marangu Branch and staff.

\subsection{The study population, sample size and sampling techniques}

A sample is a part that bears the characteristics of the population of a specific area and therefore, it is a representative of the said population (Kothari, 2004). On the other hand, sampling is a task of taking just a portion of the total population to be used in the study. Because the total population is too large to use in data collection, then a part of it is taken to adequately represent similar features of the population of the study (Krishnaswami, 2002). In this study, both probability sampling and non probability sampling were used. The study employed 
purposive and simple random strategy to get the respondents. So the sample size of the study was 130 .

Table 1: Sample size and sampling strategy

\begin{tabular}{|l|c|l|}
\hline Description & Sample Size & Sampling Strategy \\
\hline CRDB Bank Staff & 17 & Purposive Sampling \\
\hline Regular Customers from two wards & 113 & Random Sampling \\
\hline Total & 130 & \\
\hline
\end{tabular}

Population can be defined as an enormous group of people bearing similar characteristic from which a researcher can draw conclusion of the study under discussion (Creswell, 2009). The population of the study included the staff of CRDB Bank Marangu Branch and regular customers who are beneficiary of financial services of the Bank.

Table 2: Distribution of Population and Sample size

\begin{tabular}{|c|c|c|c|}
\hline \multicolumn{1}{|c|}{ Description } & Total Population & Respondents Selected & Percent of the Respondents \\
\hline CRDB Bank Staff & 25 & 17 & 0.13 \\
\hline Eastern Marangu Ward & 23,734 & 58 & 0.44 \\
\hline Western Marangu Ward & 18,976 & 55 & 0.42 \\
\hline Total & & 130 & 86.13 \\
\hline
\end{tabular}

\subsection{Types of Data and Collection Methods}

Both primary and secondary data were used. Questionnaires were used to collect primary data while secondary data were collected from books, journals, research papers, files and unpublished articles of CRDB Bank. Questionnaires are pre-printed series of queries which were sent to respondent and been return once solved (Kothari, 2004). Questionnaires were of two types. The first type was for customers and the second type was for staff intended to rank the individual saving promotion activities performed at the branch. 130 questionnaires were administered to regular customers of the Bank and staff and were both closed ended and open ended question that encouraged simple and short answers concerning the topic in question.

\section{Data analysis and Discussion}

The quantitative data have been analysed descriptively using frequency and percentages, and they have been presented by text and tables for better illustration in the tables below.

Table 3: The Socio-economic characteristics of respondents

\begin{tabular}{|l|l|c|c|}
\hline Variable & Category & Frequency & Percent \\
\hline \multirow{4}{*}{ Age } & $18-25$ & 25 & 18.9 \\
\cline { 2 - 4 } & $26-50$ & 72 & 54.5 \\
\cline { 2 - 4 } & Above 50 & 33 & 25.0 \\
\hline \multirow{4}{*}{ Marital Status } & Married & 53 & 40.2 \\
\cline { 2 - 4 } & Single & 72 & 54.5 \\
\hline \multirow{5}{*}{ Education Level } & Male & 78 & 59.1 \\
\cline { 2 - 4 } & Female & 52 & 39.4 \\
\cline { 2 - 4 } & Standard Seven & 32 & 24.2 \\
\cline { 2 - 4 } & Secondary Education & 52 & 39.4 \\
\cline { 2 - 4 } & College & 9 & 6.8 \\
\hline Occupation & University & 37 & 28.0 \\
\hline & Employed & 102 & 21.5 \\
\hline
\end{tabular}

From table 3 it can be seen that, the aging structure of the population composition at Marangu is mostly with people between the ages of $18-50$ which account for $73.4 \%$ of the population, that expected to save more as is a working age according to the basic life-cycle model; although, this age group has high life cycle encountering some expenses like household expenses, education and other social expenses, which bars them from having more savings. It is followed by $25 \%$ of those above 50 years which is a small part of the population and are disserving much as they are old and therefore, they only think of their personal life. Mahdzan \& Tabiani, (2013) posited that, savings increases with the age of the population which means that, youth of the age ranging from 18-25 do not save much as elderly; because some of them are pre-working group either in University or completed school but unemployed. The similar case is with Marangu rural. This findings are supported by the marital status of the population as most of them are not married and account for $54.5 \%$ which means most of the people are still in youth age, This status is enough to justify that, saving is not possible as they still face a lot of life expenses, which hinders them from having stable savings in banks. Few of them are married which is $40.2 \%$ of the population, this group has a sense of responsibility for their families hence they have small savings which are in intermittent level and not for long run, as Bairamli \& Kostoglou, (2000) says "the pre-working age reduces the rate of saving as parents have to take care of them for various matters that need money like school fees". The gander composition 
is $59.1 \%$ of males and $39.4 \%$ of females; studies have suggested that, men are capable of saving more because have plan for families, financial literacy and well informed on financial issues compared to women (Mahdzan \& Tabiani, 2013). In this case, there are similar findings with regards to the gender composition, as $59.1 \%$ of men account for the huge portion of savings at CRDB Bank Marangu, thus, it is true that, gender contribute to the individual saving habit (Lusardi \& Mitchell, 2007).

Education level of the population structure is as it can be seen from table 3. It is not well distributed as there is big variance between those who have College and University education which is only $34.8 \%$ of the population compared to those with standard seven and secondary education who account for $63.6 \%$ in total. It is clear that, this group has poor financial literacy and therefore, they have poor individual savings compared to educated ones as Hogarth (2002) says "Education level has positive impact to individual savings" hence educated people are capable of making good financial decisions in terms of investment, budgeting, ensuring and saving". So, the education level can justify the problem of individual saving at Marangu.

Most of Marangu people occupy small business activities which are very informal and they account for $78.5 \%$ of the population. This group has low level of education hence, they do not have good understanding of saving compared to $25.1 \%$ of the employed, and who have better understanding of personal savings and have stable Income.

Table 4: Individual saving Problems

\begin{tabular}{|l|l|c|c|}
\hline Saving problems Items & Response & Frequency & Percent \\
\hline \multirow{5}{*}{ Do you possess a Saving Account? } & Yes & 86 & 65.2 \\
\cline { 2 - 4 } & No & 44 & 33.3 \\
\cline { 2 - 4 } & Total & 130 & 98.5 \\
\hline \multirow{4}{*}{ Do you have Financial literacy } & Yes & 31 & 23.5 \\
\cline { 2 - 4 } & No & 99 & 75.0 \\
\cline { 2 - 4 } & Total & 130 & 98.5 \\
\hline \multirow{3}{*}{ Deposit habit of respondent } & Frequently & 96 & 19.7 \\
\cline { 2 - 4 } & Occasionally & 120 & 71.2 \\
\cline { 2 - 4 } & Total & 55 & 41.9 \\
\hline \multirow{5}{*}{ Factors influencing Individual saving habit } & Income & 44 & 33.3 \\
\cline { 2 - 4 } & Interest rate & 30 & 22.7 \\
\cline { 2 - 4 } & Knowledge of saving Plan & 1 & 0.8 \\
\cline { 2 - 4 } & Means of deposit made available & 130 & 98.5 \\
\hline
\end{tabular}

From table 4 , it can be seen that, those who possess saving accounts are $65.2 \%$ while those who do not are $33.3 \%$ of the population. This is a justification that, most of the opened saving accounts are not operated well. For those who do not possess accounts a means that, they either have poor understanding or have negative attitude towards saving behavior. This goes in hand with poor financial literacy, whereby $75.0 \%$ of the population is not well informed about financial issues compared to $23.5 \%$ who have financial literacy.

It can also be seen that, the deposit habit of respondent is very poor as those who save on frequent basis account for $19.7 \%$ while those who save occasionally is $71.2 \%$ of the total population. Most of individual saving comes from income contribution which is $41.7 \%$ and followed by interest rate which is $33.3 \%$.

Table 5: Saving Accounts at CRDB Marangu Branch in five years

\begin{tabular}{|rcr|r}
\hline Year & Targeted Saving Account to be opened & Actual Saving Account Opened & $\begin{array}{c}\text { Total } \\
\text { Saving } \\
\text { Account }\end{array}$ \\
\hline $\mathbf{2 0 1 7}$ & 4000 & 5000 & 25000 \\
$\mathbf{2 0 1 6}$ & 3000 & 5000 & 20000 \\
$\mathbf{2 0 1 5}$ & 3000 & 4000 & 15000 \\
$\mathbf{2 0 1 4}$ & 3000 & 5000 & 11000 \\
$\mathbf{2 0 1 3}$ & 1000 & 1500 & 6000 \\
\hline
\end{tabular}

Table 5 above shows the number of saving accounts opened since 2013. The number of saving account has grown rapidly from 6000 to 25000 in the end of the year 2017. It can be seen that, every year target of having new saving were exceed. The average branch target for opening new saving accounts each year is 5000 accounts, although most of these opened saving accounts were found to be dormant besides the effort undertaken by the branch to recruit many new saving accounts with expectation of increasing deposit from individuals but these efforts has been found to be relatively worthless due to poor saving behavior. Dormant accounts in this Branch were about $50 \%$ of account opened each year according to Branch Supervisor. So, it is real a challenge to branch as it incurs a lot of costs in opening individual saving account as the bank is forced to sell its debit cards at low price below its production cost just to inspire individuals and mobilize this kind of saving, and the extra cost is 
transferred to customers as they continue using the account which is still a problem as customers are sensitive to account operational cost. The challenge of having dormant saving account was found in the branch report whereby; in the year 2017 actual deposits were Tsh 14 Billion while the target deposits were Tsh 17 Billion. Hence, there was a deficit of three (3) Billion, which is an indicator of failure in mobilizing individual saving.

In inspiring individuals to have saving account, the branch organized Individual saving promotion activities to achieve its goals, whereby ten of the core activities were performed at the branch level. The activities were on account opening, agents, marketing, promotion, rewards, and incentives to staff; deposit the target and customer service. The selection of each strategy was developed in an interview with business department, which is responsible for insuring banking business exist and well supplied with adequate fund from deposit. The finding on individual saving promotion activities has been summarized in Table 6 .

Table 6: Individual Saving promotion activities

\begin{tabular}{|l|c|c|c|c|}
\hline & $\mathrm{N}$ & Mean & $\begin{array}{c}\text { Std. } \\
\text { Deviation }\end{array}$ & $\begin{array}{c}\text { Std. Error } \\
\text { Mean }\end{array}$ \\
\hline We open more account every day. & 17 & 1.00 & $.000^{\mathrm{a}}$ & .000 \\
We sometimes reduce cost of account opening. & 17 & 1.53 & .514 & .125 \\
We recruit more agents to save our customers. & 17 & 1.29 & .588 & .143 \\
We market our new saving facility before launching them. & 17 & 2.65 & .702 & .170 \\
We run different promotions and games to encourage individuals & 17 & 1.94 & .899 & .218 \\
to save. & 17 & 1.00 & $.000^{\mathrm{a}}$ & .000 \\
We set maximum deposit target. & 17 & 1.35 & .493 & .119 \\
We do marketing for our existing saving products regular. & 17 & 1.53 & .514 & .125 \\
We offer gifts to our Loyal saving customers. & 17 & 1.24 & .664 & .161 \\
Bank offers incentives for staff that brought significant deposits. & 17 & 1.47 & .514 & .125 \\
We offer best customers service. &
\end{tabular}

The branch used two strategies such as opening account and setting maximum deposit as a tool for mobilizing individual savings. The mean average of staff, who claimed opening more accounts and set maximum deposit target, was 1.00 and 1.00 respectively.

The higher frequency of respondent who responded either bank set maximum deposit or opening more accounts does not necessarily mean the impact of this target is directly seen at individual level. The institution deposit target is collectively as each branch under the main institution is allocated with the target to hit and no remarks are inserted towards mobilization of saving from individuals. The findings observed that, this particular institution has a relatively high tendency of marketing its new products before launching as it mean is 2.65 which is high and this is the only activity which is done well. Astonishly, most of products available with the branch are not known well by majority, it is only known by few individuals despite all effort undertaken in marketing new products. Moreover, there is poor habit of the branch in rewarding their loyal saving customers as it mean score is 1.53 , as well as lower tendency of running different games or tournaments for their existing saving customers as it mean score is 1.94 .

Interview was made with Bank Development Officer (BDO) regarding Problems encountered by CRDB Bank in promoting Individual Saving and he established the following Problems:- Competition from MNOs like M-Pesa, Tigo-Pesa and Airtel Money. BDO acknowledged that, many people prefer the use of MNOs as they are convenient and flexible, Community reluctance to learn issues of saving and deposit. Bank officers have received less attention when trying to educate community in public places, Low individual income with less motivation to saving, Demand for higher deposit interest rate, Individual have no saving habit, Low money circulation to promote economic activity, Complaints over procedures and cost of account opening and low financial literacy, CRDB Account opening cost is higher compared to close competitors.

\section{Findings of the study}

The bank has not yet been effective in the creation of financial capability and training programmes that would teach people best practices, such as basic budgeting, separating money saved for different goals and uses.

Individuals have negative attitude toward saving with Bank and some suggested that, Banks are only for business persons who have regular income and not for those with irregularly income.

Account opening tool is less effective in recruiting more savers than creating many dormant accounts.

Interest rates and income were seen to impact levels of individual savings.

The efforts and resources placed by CRDB Bank in promoting savings is high compared to the saving rates whereby, many saving account are opened each year but they become dormant in one year after been opened.

Most of the People residing in Marangu are low income earners and therefore, they save much of their earnings informally and at shorter intermittent level.

Most of products available with the branch are not known well by majority, it is only few individuals who 
are aware. This goes in hand with poor habit of the branch in rewarding their loyal saving customers as it mean.

\section{Recommendations}

In strengthening efforts of financial institution in promoting savings, the followings needs to be done

- Mass education on saving plan by launch financial training workshops and financial advice to public through various media.

- The bank should assist staff in realizing their role in promoting individual saving.

- Review procedure and costs subjected to account opening and operations.

- Increase deposit interest rate to a reasonable level to stimulate saving.

- Launch of other product or facilities, that will motivate saving from low income earner to save, like looking at what strategies are being used by other financial institutions in mobilizing savings.

- Assisting Individuals to have habit of participating in financial education workshops.

- Promoting individual saving habit programmes by the bank to Primary, Secondary, College and University students to help them grow with the mentality of saving.

- Policy makers can sensitize the rural people of Marangu to diversify some of their land uses into non agricultural activities like conduction of various business activities that would guarantee income generation to increase saving rate of the rural people.

- The bank should struggle to change peoples' perceptions towards saving, that banks are not there for business persons only, for instance, coming with adverts demonstrating the value of having savings.

\section{References}

Annamaria, L. (2000). Household Savings Behavior in the United States: The Role of Literacy, Information, and Financial Education Programs.

Bairamli, N., \& Kostoglou, V. (2010). The Role of Savings in the Economic Development of the Republic of Azerbaijan. International Journal of Economic Sciences and Applied Research 3 (2): 99-110

Browning, M., \& Lusardi, A,. (1996). Household saving: micro theories and micro facts. Journal of Economic Literature. $\quad$ Vol. $\quad 34, \quad$ No. $4 \quad$ (Dec., 1996 ), pp. https://pdfs.semanticscholar.org/3fc3/3e21501c42b6fc5d2048d27985f762f80432.pdf

Crossley, T., Emmerson, C., \& Leicester. ( 2012). Raising Household Saving. British Academy Policy Centre Publication.

Edla. (2018), Financial Insitution. Retrieved from Investopedia: www.investopedia.com

Erkki, \& Jouko. (1992). Savings Behavior: Theory, International Evidence and Policy Implications: Editors' Introduction. The Scandinavian Journal of Economics, 94 (2).

Gustman, A., \& Steinmeier.,T. (2004), "What People Don't Know about their Pensions and Social Security," in William Gale, John Shoven and Mark Warshawsky (eds.), Private Pensions and Public Policies, Washington, DC: Brookings Institution, pp.57-125.

Hall, S., Pettigrew, N., \& Bell, S. (2007). Saving in ISAs: Final Report 22/10/07. London: HMRC.

Hogarth, J.M. (2002), Financial Literacy and Family and Consumer Sciences”, Journal of Family and Consumer Sciences, Vol. 94, No 1, pp.15-28.

Kempson, E., Atkinson, A., \& Collard, S. (2006). Saving for children: A baseline survey at the inception of the Child Trust Fund. HM Revenue \& Customs Research Report 18, London: HMRC.

Keynes, J. M,. (1936). The General Theory of Employment, Interest and Money. Macmillan Cambridge University Press, for Royal Economic Society in 1936, United Kingdom.

Keynes. J. M,. (1936). The General Theory of Employment, Interest and Money. Palgrave Macmillan, United Kingdom.

Kothari, C. (2004). Research Methodology Methods and Techniques (Second ed.). New Age International (P) Ltd., Publishers. 4835/24, Ansari Road, Daryaganj, New Delhi - 110002

Lusardi, A., and Mitchell, O.S. (2007), "Financial literacy and Retirement preparedness. Evidence and implications for Financial Education", Businee Economics, Vol. 42, No 1, pp. 14A-15A.

Mahdzan, N.S., Tabian,S. (2013), "The impact of financial Literacy on Individual savings: an exploratory study in the Malaysian Context", Transformations in Business \& Economics, Vol.12,No 1 (28), pp. 41-55

Mckinnon, R. (1973). Money and Capital in economics development. Washington D.C: Brookings Institution.

Mohammed, A. A., Alexande, r. S., \& Musa, G. G. (2015). The Impact of Target Deposit Mobilization on the Banking Industry: A Study of Selected Banks in Maiduguri Metropolis. Department of Finance University of Maiduguri.

Msabila, D. (2001). Comprehencive Economic Review. Dar-es salaam: Nyambari Nyangwine.

Paul, W. (1977). Inflation, Uncertainty, and Saving Behavior since the Mid-1950s. In Z. Victor, \& H. M. Geoffrey, Explorations in Economic Research (Vol. 4). NBER. 
Role Of Banks Financial Institutions In Economic Growth Economics Essay. (n.d.). UKessays TRUSTED BY STUDENTS SINCE 2003 . Retrieved January 06, 2018, from https://www.ukessays.com/essays/economics/role-of-banks-financial-institutions-in-economic-growtheconomics-essay.php

Roy, H., \& Webb. (1992) Personal Saving Behavior and Real Economic Activity. https://pdfs.semanticscholar.org/54d5/1ec896fea858bcdefd9fe90f007815cb06c8.pdf

Sarah, B., \& Karl, T. (2016). Early influences on saving behaviour: Analysis of British panel data. Journal of Banking \& Finance, 62, 1-14.

Savings. (2018). Retrieved from Busiiness Dictionary: www.businessdictionary.com

Thirlwall, A., (2002). 'The mobilization of savings for growth and development in developing countries', Icfai University Journal of Applied Economics, 1, 1, pp. 7-30.

Walter, A., Holzle, K., \& Ritter, T. (2002). Relationship functions and customer trust as value creators in relationships. A conceptual model and empirical findings for the creation of customer value. Proceedings of the 18th IMP conference, .

Wells, J. (2008). An inclusive approach to financial products. London: Age Concern.

Population and Housing Census (PHC) for United Republic of Tanzania, (2012). http://www.tzdpg.or.tz/fileadmin/documents/dpg_internal/dpg_working_groups_clusters/cluster_2/water/W SDP/Background_information/2012_Census_General_Report.pdf 